he served as president of the ACRL/OK chapter and on the Chapters Council. He founded and edited for 15 years the journal Conservation Administration News, which reported on the library and archival preservation field. In 1989 he was CLR UCLA Senior Fellow.

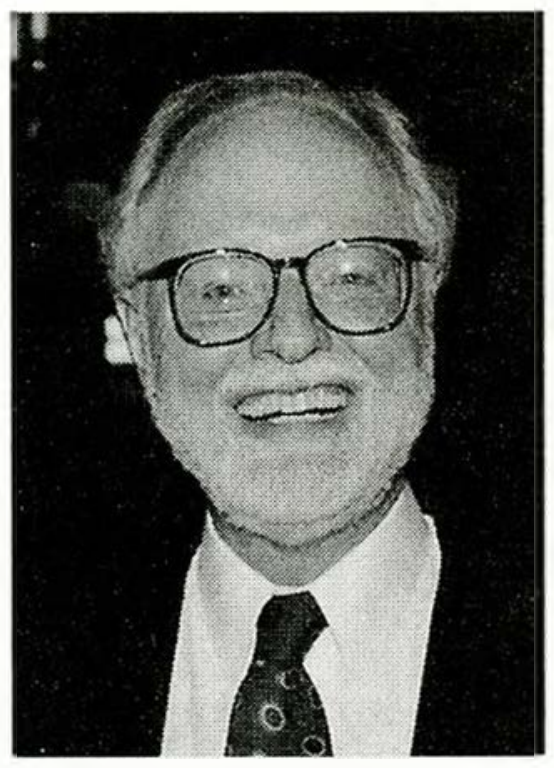

Robert H. Patterson

\title{
De aths
}

Kimball C. Elkins, who retired as curator from the Harvard Library in 1971, died at the age of 94 on September 14, 1997. Elkins graduated from Harvard College in 1927 and received an A.M. in History in 1933. He joined the Documents Division of the library in 1928 and transferred to the university archives in 1943 as senior assistant. Elkins published a number of articles in the Harvard Library Bulletin and Harvard Alumni Bulletin (now the Harvard Magazine), on such Harvard subjects as the Quaker collection in the library, the use of Harvard-owned maps to help settle the Maine border dispute that resulted in the Webster-Ashburton Treaty, the history of honorary degrees, and birds in Harvard Yard.

Marie Genung, retired reference librarian at the University of California, Riverside (UCR), died on December 28, 1997. Genung began her career at UCR in 1951 to help prepare for the opening of the new general campus of the university. She had a library certification from UC Berkeley, and had worked for five years as a cataloger at Mills College in Oakland, California. She organized the cataloging department of the UCR Library and was the department head until 1963. She had combined responsibilities as a bibliographer, cataloger, and reference librarian for the next ten years, and then worked full-time in Rivera Reference until her retirement in 1986, after 35 years of service.

Robert W. Lovett, retired archivist for the Harvard University Libraries, died on June

14, 1996. Lovett graduated from Harvard with an A.B. in 1935. Lovett's archives and manuscripts career began at the Harvard University Archives in 1937. He served there until 1948 when he accepted a position in charge of the Manuscript and Archives Division of the Harvard Business School Library. For two decades he divided his time between the Business School and the Medical School, where he developed an archive. The last decade of his career he spent at the Business School, from which he retired in August 1979. Lovett was recognized relatively early in his career with election as a Fellow when the Society of American Archivists established that category in 1958. Among his other honors and offices was an award in 1979 by the Southern New England Chapter for the Society for Industrial Archaeology, election in 1960 to honorary membership in the Alpha Chapter of Phi Beta Kappa at Harvard, and in 1984 he received a silver bowl for contributions to the city of Beverly. Lovett was also a prolific writer, and his bibliography of books, articles, and reviews numbers over 100 items.

Mary M. Meehan, university archivist for the Harvard University Library, died October 11, 1997. She helped develop the collections of the Harvard University Archives during the middle decades of this century. She graduated from Radcliffe College in 1934 and in 1946 she came to the Harvard University archives, working on a variety of projects in a number of positions until her retirement in 1975 .

\section{Advertisers index}

$\begin{array}{lr}\text { Almanac Publishing } & 287 \\ \text { American Institute } & \\ \text { of Chemical Engineers } & 237 \\ \text { Amigos } & 289 \\ \text { Blackwell's Book Services } & 252 \\ \text { Blackwell's Info. Services } & 281 \\ \text { Canadian Museum of Nature } & 290 \\ \text { Choice } & 240 \\ \text { CIS } & \text { Cover 4 } \\ \text { EBSCO } & \text { Cover 3 } \\ \text { Minolta } & 282-283 \\ \text { OCLC } & 300 \\ \text { Primary Source Media } & 293 \\ \text { Spacesaver } & \text { Cover } 2\end{array}$




\section{WHY DO 10,987 LIBRARIES IN 56 COUNTRIES USE THE OCLC FirstSearch SERVICE?}

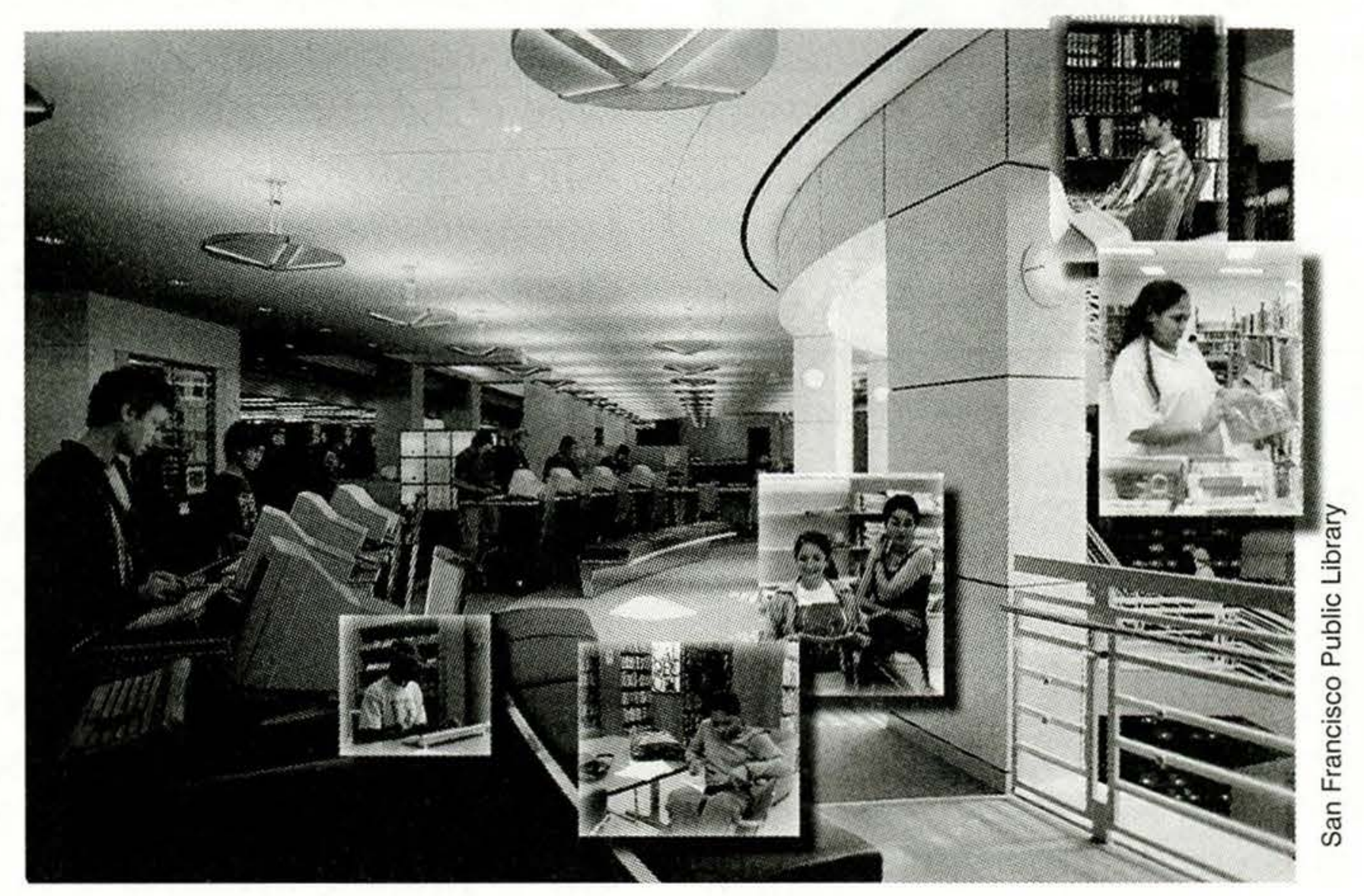

\section{Comprehensiveness}

- OClC World Cat (THe OClC Online Union Catalog) the most frequently consulted database in higher education

- New York Times, the most recent 90 days of articles with abstracts since 1994

- Ca Student Edition, a customized Chemical Abstract Services collection for undergraduates

- oclC FirstSearch Electronic Collections OnLINE SERVICE, a critical mass of scholarly journal articles

- oclC NetFirst database, unparalleled subject access to Internet resources

- Over 60 other databases covering humanities, science, social studies, and more

\section{Full-TeXT}

- More than one million newspaper and journal articles for immediate online viewing or e-mail delivery

- Electronic reference files: encyclopedias, almanacs, phone books, directories, financial reports

- Patron generated full-text document delivery via interlibrary loan, fax and mail

\section{FLeXibILITY}

- Seamless integration with your collection, LAN, Web services, ILL, online full text and document delivery

- Mix and match databases, full text, access level, and payment plans to best serve the needs of your users

- Choice of TTY, Web, or Z39.50 interface options

- Affordable pricing options: per-search or subscription, individual or group www.oclc.org

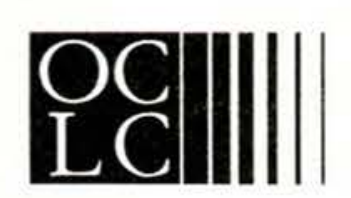

Furthering Access to The World's Information 